\title{
BIRD DIVERSITY ON RECLAIMED NICKEL MINE-LAND IN KOLAKA DISTRICT SOUTHEAST SULAWESI
}

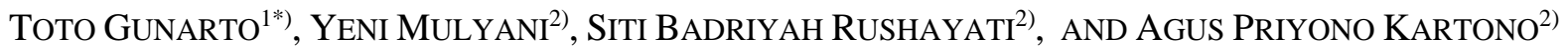 \\ 1) Conservation of Tropical Biodiversity, Graduate School, IPB University, Dramaga Campus, Bogor, 16680, Indonesia \\ 2) Department of Forest Resources Conservation and Ecotourism, Faculty of Forestry and Environment, IPB \\ University,Bogor, 16680, Indonesia
}

*Email: toto.forest19@gmail.com

Accepted August 10, 2021 / Approved September 12, 2021

\begin{abstract}
Nickel mining is one of open type mining having a high risk on environment. Birds are often used as indicators of habitat change in reclaimed mine-land. The objectives of this study were (1) to identify bird species; (2) to compare bird communities; (3) to predict biotic and abiotic factors that affect bird communities in mining reclamation land according to the age of reclamation, and natural forest in nickel mining area. This research was conducted on reclaimed land in 2006, 2007, 2008, 2009. The composition of bird species is described based on family, endemicity and feeding guild. Bird data were analyzed using Shannon index, Jacknife index, and Sorensen community similarity. Estimation of environmental factors is calculated using multiple regression analysis. This study discovered 41 bird species from 23 family classified into 7 guilds. There were 17 Sulawesi endemic species, and one of them is categorized as vulnerable by IUCN (Rhabdotorrhinus exarhatus). The highest species richness and diversity was found in year 2006 reclamation land (34 species, $\left.S=44, H^{\prime}=3,08\right)$. The highest similarity analysis of bird communities was in 2006 reclaimed land and natural forest $(\mathrm{Cn}=0,79)$. Based on the results of multiple regression analysis, 3 variables significantly affect the presence of birds (the insect abundance, number of tree species, and the closest perpendicular distance to the river). The presence of birds is influenced by food sources (insects, fruit) and the presence of water. The composition of bird species approached natural conditions with increasing age of reclaimed land.
\end{abstract}

Key words: bird, community, diversity, mine, reclamation

\section{INTRODUCTION}

Mining is one of the core sectors that drive growth economy. The mining industry contributed about $7.36 \%$ to Indonesian GDP in 2017 (Kemenperin 2017). Indonesia is the world's largest producer of nickel (USGS 2020), and produces around 1.78 million ton (ESDM 2020) with export value more than 796.2 million USS in 2019 (BPS 2020). Most of Indonesia's proven nicke reserves are located in southeast of Sulawesi, Halmahera, and Gag island (INSG 2018). According to data from BPS (2020), 148 of 221 mining companies in southeast Sulawesi are nickel companies and distribution of nickel mining areas are in Kolaka,North Kolala, Konawe, North Konawe, Bombana, South Konawe, and Buton.

Nickel mining is one of open type mining (Hidayat 2015) that has a high risk on environment due to clearing of all aboveground vegetation, transfer of topsoil to the stockpile (Aldiansyah and Nursalam 2019) and causes various diseases (Darmono 2011). According to Peraturan Menteri ESDM No. 26 tahun 2018, the mining companies are obligated to reclamation the post mining areas. Reclamation activities are expected to restore environmental sustainability and improve the quality of people's live (Maga et al. 2017).

Birds are often used as indicators of habitat change in reclaimed mine-land because of their various characteristics. Birds are sensitive to environmental changes, such as natural disturbances, human, disease
(Morisson 1986), or environmental pollution (Furness 1993). Birds took various natural resources (nectar, fruit, insect) in their surroundings to survive (Brady 2005). The ability of birds as indicator of habitat is characterized that each bird has a close relationship with one or more habitats and can be classified as specialist or generalist (Julliard et al. 2006). Moreover, birds acting as pollinator play an important role in ecosystem, especially in reclamation areas (Yassir et al. 2013). Most species of birds are diurnal, it is relatively easy to identify and observe (Brady and Noske 2009).

Previous studies about bird communities and diversity on forestland degradation, such as ex-coal mining land (Boer 2009; Soegiharto et al. 2013) were reported. However, those studies in ex-nickel mining land were limited. The presence of birds on reclaimed land helped the succession process to be faster naturally and the presence of new plants became a new habitat for birds (Yassir et al. 2013). The objectives of this study were (1) to identify bird species in mining reclamation land according to the age of reclamation, and natural forest in nickel mining area; (2) to compare bird communities in mining reclamation land according to the age of land reclamation and natural forest in nickel mining area; (3) to predict biotic and abiotic factors that affect bird communities on reclaimed mine-land and natural forests in nickel mining sites. 


\section{RESEARCH METHOD}

This study was carried out on August 2017 in nickel mining areas in Kontrak Karya PT. Vale Indonesia Tbk unit Pomalaa, Desa Huko-Huko, Kecamatan Pomalaa, Kabupaten Kolaka Sulawesi Tenggara (Figure 1). Kolaka

Birds were observed by using the point count method (Bibby et al. 2000; Rahayuningsih et al. 2007). In each type of location (Table 1), 11 random point (radius $50 \mathrm{~m}$ ) were established to collect bird data. The distances between the observation point were $100 \mathrm{~m}$. Duration for bird observation in each point was 10 minutes (Smith et al 1998). Observation was held twice a day. In the morning (06.00-09.00 WITA) and in the afternoon (15.00-18.00 WITA) (Dewi et al. 2007). Each point was replicated three times in different days. Identification of bird species based on the study's result was done descriptively using bird field guide in Wallacea (Coates and Bishop 2000). The bird naming is adjusted to Indonesian Bird List 2 (Sukmantoro et al. 2007).

The status of each bird observed were recorded based on IUCN RedList (IUCN 2020) and government regulation status (KLHK 2018). Birds were classified a received 8.9 - 368,9 $\mathrm{mm}$ of rainfall annually (type B of Schmidt and Ferguson system). The study area was a low hilly area (200-500m above sea level) and the slope of about $0-40 \%$. The data were taken in four type of reclamation land based on the year of reclamation (in 2006, 2007, 2009, and 2016).

priori into feeding guilds (Wiens 1989) based on previous reports, such as MacKinnon (1990). Vegetation data were collected used vegetation analysis (Soerianegara and Indrawan 1980). This method created single plot (Figure 2) in each type reclamation land. Measurement at seedling level (the height of sample $<1.5$ $\mathrm{m}$ ) use a $2 \mathrm{~m} \times 2 \mathrm{~m}$ plot. Stake level (the height of sample $>1.5 \mathrm{~m}$ and stem diameter $<10 \mathrm{~cm}$ ) take $5 \mathrm{~m} \times 5 \mathrm{~m}$ plot. Pile level (plant diameter between 10-20 cm) use $10 \mathrm{~m} \mathrm{x}$ $10 \mathrm{~m}$. The tree level (diameter $>20 \mathrm{~cm}$ ) use $20 \mathrm{~m} \times 20 \mathrm{~m}$. Parameters measured diameter, height (especially tree level), name, and number of individuals. The parameters were calculated to have Importance Value Index (IVI) representing vegetation analysis. In this study, data of phenology plants recorded were in flowering phase and fruiting phase.

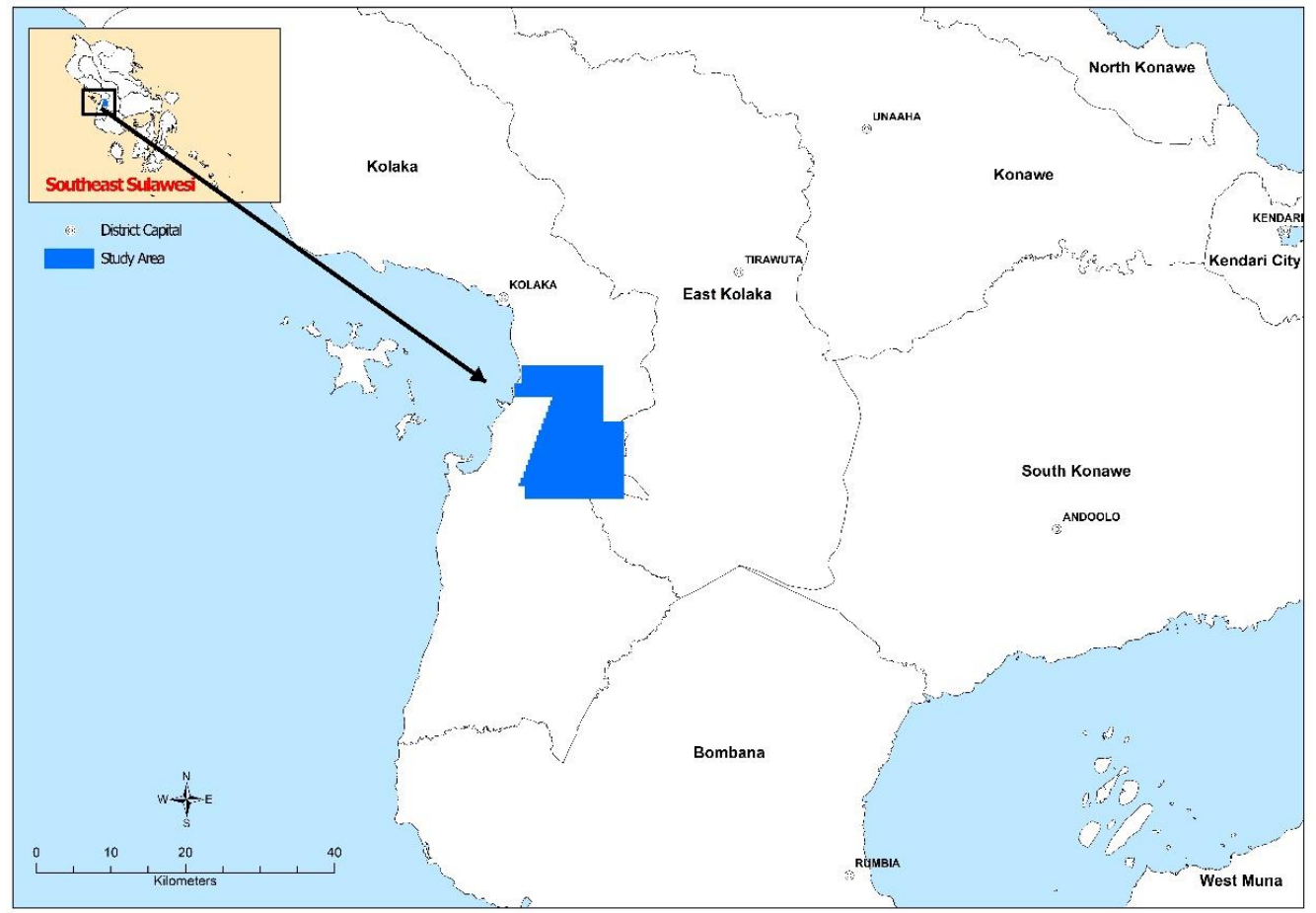

Figure 1. Research site map

Table 1 The number of research sample point

\begin{tabular}{cccc}
\hline No & Research sites & Area (ha) & Number of sample point (n) \\
\hline 1 & 2006 & 22,28 & 11 \\
2 & 2007 & 25,93 & 11 \\
4 & 2009 & 8,91 & 11 \\
6 & 2016 & 8,75 & 11 \\
7 & Natural forest & 15028,91 & 11 \\
\hline & Total & 15104,80 & 55 \\
\hline
\end{tabular}




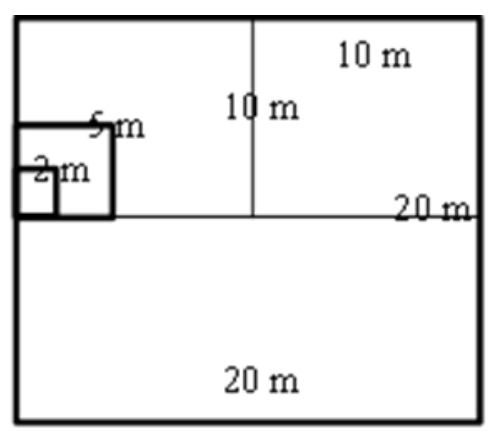

Figure 2. Single plot of vegetation analysis

Insect data collection were done by using two methods, namely branch shaking (Stone dan Bacon 1994) and sweep netting (Meijer et al. 2012). After insect were caught, insect would be sorted using microscope binocular and preserved in 55\% alcohol solution. Information about the location of the discovery and the type of plant is attached to the preserved bottle (N'Djolossè et al. 2012). Morphology of preserved insects were identified by the whole mount method and insect would be classified based on ordo. Identification of insect refers to Borror et al. 1996 and Insect of Australia (CSIRO 1991).

Data analysis was conducted to get parameters such as the richness of species, diversity, evenness, dominancy, and similarity of bird communities. Jackknife index is used to estimate the total species richness (Magurran and McGill 2011). The value of bird species diversity was described by using the shannonwiener index (Ludwig and Reynolds 1988). The abundance proportion of bird species in each habitat type and land escape was calculate using Evenness index (Rahayuningsih et al. 2007). Dominancy index is used in order to determine dominant bird in research area (Helvoort 1981). The similarity of bird communities was examined by Sorensen similarity index (Magurran, 2004).

Estimation of environmental factors that affect the presence of bird species on mine reclamation land is calculated using multiple regression analysis and linear models $(\alpha=5 \%)$ with the formula (Walpole 1992):

$$
\gamma=b_{0}+b_{1} x_{1}+b_{2} x_{2}+\ldots+b_{6} x_{6}
$$

Notation: Y represents the number of bird species, $\mathrm{b} 0=$ constant coefficient value, $\mathrm{bi}=$ correlation coefficient to $\mathrm{i}, \mathrm{X} 1=$ Temperature, $\mathrm{X} 2=$ closest perpendicular distance to primary forest $(\mathrm{km}), \mathrm{X} 3=$ the closest perpendicular distance to the settlement $(\mathrm{km}), \mathrm{X} 4$ = number of individual trees bearing fruit/flowering, X5 $=$ number of individual insects, $\mathrm{X} 6=$ number of tree species and $\mathrm{X} 7=$ closest perpendicular distance to the river.

The tested hypotheses are:

$\mathrm{H} 0$ : $\mathrm{bi}=0$, none of the $\mathrm{X}$ variables affect the $\mathrm{Y}$ variable
$\mathrm{H} 1$ : bi $\neq 0$, there is at least one independent variable $\mathrm{X}$ that affects the variable $\mathrm{Y}$.

\section{RESULT AND DISCUSSION}

\section{Bird species composition}

A total of 41 bird species from 23 families were found during the study. One species of migratory bird was also found, i.e. Rainbow Bee-eater (Merops ornatus). The bird migrated to northern Australia, especially Lombok and Sulawesi during winter season and return to Australia's continent to breed (Boland 2004). This study was conducted on August when it was winter season in Australia.

Accipitridae family is the family with the highest number of species. Although the number of each species was only 1-2 individuals. This family is birds of prey (raptors) and occupies a position at the top of the food chain. The presence of raptors indicated relatively good habitat conditions. Sergio et al. (2006) reported an area would have a high diversity of birds and vegetation if many predators inhabited the area. The location of reclaimed in 2006 had the highest number of birds of prey (three species). Moreover, Jerdon's baza species was a raptor found in both natural forest and reclaimed land in 2006. This indicated that the habitat quality of the 2006 reclaimed land was good enough. One of waterbird species found in reclaimed land in 2009, namely little pied cormorant (Phalacricorax melanoleicos). The existence of this waterbird was supported by the presence of aquatic habitat, such as lakes.

17 bird species were classified to Sulawesi endemic species, i.e. yellow-billed malkoha (Rhamphococcyx calyorhynchus), grey-side flowerpecker (Dicaeum celebicum), yellow-sided flowerpecker (Dicaeum aureolimbatum), Sulawesi pygmy woodpecker (Picoides temminckii), dark-eared myza (Myza celebensis), Sulawesi hawk-eagle (Nisaetus lanceolatus), Sulawesi serpent eagle (Spilornis rufipectus), grosbeak starling (Scissirostrum dubium), Sulawesi white-eye (Zosterops consobrinorum), Sulawesi hornbill (Penelopides exarhatus), white-rumped triller (Lalage leucopygialis), Sulawesi cicadabird (Edolisoma morio), Sulawesi 
babbler (Trichastoma celebense), ashy woodpecker (Mulleripicus fulvus), Sulawesi myna (Basilornis celebensis), white-necked myna (Streptocitta albicollis), and great hanging parrot Loriculus stigmatus). Two species among them, which are dark-eared myza and grosbeak starling, were endemioc to Sulawesi at genus level (Prawiradilaga 2019). The amount of Sulawesi endemic species discovered in this study were equal to the previous study from Mustari et al. (2012) in Bantimurung Bulusaraung National Park (16 species). Sulawesi was included in the Wallacea region having the highest endemicity in Indonesia so many endemic birds were found in this study (Prawiradilaga 2019).

According to IUCN Red List (2020), 41 bird species were included in three categories, i.e. Near threatened (NT), Vulnerable (VU), and Least Concern (LC) (Table 2). Two of them were classified into near threatened, namely rufous-bellied eagle (Hieraaetus kienerii) and yellowish-breasted racquet-tail (Prioniturus flavicans). Sulawesi hornbill was categorized into vulnerable. Meanwhile, 38 bird species were grouped by least concern. It concluded that the majority of birds living on reclaimed land were bird species with a low extinction rate.

10 bird species were protected by the Government of Indonesia under Ministry of Forestry and Environment (KLHK) 2018 (Table 2). Eight of them were recorded on Convention on International Trade in Endangered Species of Wild Fauna dan Flora (CITES) classified on Appendix II, namely jedon's baza (Aviceda jerdoni), Sulawesi serpent eagle (Spilornis rufipectus), black eagle (Ictinaetus malayensis), rufous-bellied eagle (Hieraaetus kienerii), Sulawesi hawk-eagle (Spizaetus lanceolatus), yellow-breasted racquet-tail (Prioniturus flavicans), Sulawesi hanging-parrot (Loriculus stigmatus), and Sulawesi hornbill (Penelopides exarhatus) (Tabel 2).

According to predominantly feeding (guild), 41 species were divided into seven guilds, i.e. 18 species of insectivores, 7 species of frugivores, 6 species of nectarivores, 5 species of carnivores, 2 species of piscivores, 2 species of omnivores, and 1 species of granivores. The number of insectivorous birds was high dominance. It indicated that the insectivorous bird dominated in each type of habitat (Sastranegara 2018).

\section{Bird Richness and bird diversity}

The total species richness was calculate using Jackknife index $(\mathrm{S})$. The value of Jackknife index was ranging from 21.45 to 44 . The highest species richness was in 2006 reclaimed land (Tabel 3). The different values of bird richness in each reclaimed land were related to the different ages of reclaimed land. Reclaimed land in 2006 was the first of reclamation activities in those ex-mining land. Meanwhile, reclaimed land in 2016 was one years old. The age of reclamation affected to the complexity of vegetation. In reclaimed land in 2006, the vegetation consisted of pioneer tree species, such as sengon or sengon buto with the height of 20-40 $\mathrm{m}$, and shrubs, likes melastoma and komba-komba. This condition supported the high number of bird species at this location because birds tend to use tree canopy (Vikar et al.2020).

Table 2 Threat status, trade, adn protection of bird species in mione reclamation land.

\begin{tabular}{|c|c|c|c|c|}
\hline Latin Name & Family & IUCN Red List & Permen LHK No.106/2018 & CITES \\
\hline Aviceda jerdoni & Accipitridae & $\mathrm{LC}$ & $\mathrm{D}$ & II \\
\hline Spilornis rufipectus & Accipitridae & $\mathrm{LC}$ & $\mathrm{D}$ & II \\
\hline Ictinaetus malayensis & Accipitridae & $\mathrm{LC}$ & $\mathrm{D}$ & II \\
\hline Hieraaetus kienerii & Accipitridae & NT & $\mathrm{D}$ & II \\
\hline Spizaetus lanceolatus & Accipitridae & $\mathrm{LC}$ & $\mathrm{D}$ & II \\
\hline Prioniturus flavicans & Psittacidae & NT & $\mathrm{D}$ & II \\
\hline Loriculus stigmatus & Psittacidae & $\mathrm{LC}$ & $\mathrm{D}$ & II \\
\hline Penelopides exarhatus & Bucerotidae & VU & $\mathrm{D}$ & II \\
\hline Mulleripicus fulvus & Picidae & $\mathrm{LC}$ & $\mathrm{D}$ & \\
\hline Aethopyga siparaja & Nectariniidae & $\mathrm{LC}$ & $\mathrm{D}$ & \\
\hline
\end{tabular}

Description $: \mathrm{LC}=$ Least Concern, $\mathrm{NT}=$ Near Threatened, $\mathrm{VU}=$ Vulnerable, $\mathrm{D}=$ Protected 
Bird species diversity was different in each reclaimed land (Tabel 3). The highest species diversity was found in year 2006 reclamation land $\left(H{ }^{\prime}=3,08\right)$, while the lowest bird diversity was found in 2016 reclaimed land $\left(\mathrm{H}^{\prime}=2,11\right)$. Bird diversity in 2006 reclaimed land was higher than the others. It was influenced by (a) reclamation ages effecting to vegetation (Hawkins et al. 2005); (b) an availability of feed sources (Karr 1988), (c) the large area of reclaimed land (habitat) (Fachrul 2008).

The low species diversity in 2016 reclaimed land was greatly involved by the low vegetation strata in that area. Basen on vegetation analysis data, tree levels were not found in 2006 reclaimed land. Bird species diversity in reclaimed land will be similar to surrounding forest with time along (Brady 2005). In other hand, the value of diversity index of natural forest was lower than that of 2006 and 2007 reclaimed land. It was due to fires in natural forest area in 2015. It is concordance with Herrando and Broton (2002) that bird prefer to choose forest cover as a habitat for breeding and foraging so fires in forest disturbed diversity species bird.

Evenness index range (E) in different ages of reclaimed land was from 0.76 to 0.87 (Tabel 3). Kaban (2018) reported that if the value of evenness index was above 0.5 , the evenness of species at observation location was classified into high category. Tabel 3 mshowed all reclaimed land had the high category of species evenness. The high of evenness index showed the proportion of bird discovered was more balanced (Wiens 1992). It indicated that none of the bird species found dominate.

\section{Dominant bird species}

During this study, 8 dominant bird species was discovered in 2006 reclaimed land, namely olive-backed sunbird (Cinnyris jugularis), grey-sided flowerpecker (Dicaeum celebicum), sooty-headed bulbul (Pycnonotus aurigaster), rainbow bee-eater (Merops ornatus), Sulawesi hanging-parrot (Loriculus stigmatus), haircrested drongo (Dicrurus hottentottus), glossy swiftlet (Collocalia esculenta), and black-naped fruit dove (Ptilinopus melanospila). In 2007 reclaimed land, 7 of them were dominant bird species, i.e. olive-backed sunbird (Cinnyris jugularis), grey-sided flowerpecker (Dicaeum celebicum), yellow-sided flowerpecker
(Dicaeum aureolimbatum), white-collared kingfisher (Halcyon chloris), rainbow bee-eater (Merops ornatus), Sulawesi babbler (Trichastoma celebense), hair-crested dongo (Dicrurus hottentottus), grey-rumped treeswift (Hemiprocne longipennis), and glossy swiftlet (Collocalia esculenta). 5 dominant bird species was discvovered in 2009 reclaimed land, such as black sunbird (Leptocoma sericea), olive-backed sunbird (Cinnyris jugularis), grey-sided flowerpecker (Dicaeum celebicum), rainbow bee-eater (Merops ornatus), and Sulawesi hanging parrot (Loriculus stigmatus). 5 dominant bird species were found in 2016 reclaimed land, likes olive_backed sunbird (Cinnyris jugularis), sooty-heade bulbul (Pycnonotus aurigaster), pied bush cat (Saxicola caprata), lemon-bellied white-eye (Zosterops chloris), and rainbow bee-eater (Merops ornatus). 8 species bird was dominant bird in natural forest, i.e. black sunbird (Leptocoma sericea), crimson sunbird (Aethopyga siparaja), yellow-sided flowerpecker (Dicaeum aureolimbatum), pale-bellied white-eye (Zosterops consobrinorum), rainbow bee-eater (Merops ornatus), yellow-breasted racquet-tail (Prioniturus flavicans) Sulawesi babbler (Trichastoma celebense), and glossy swiftlet (Collocalia esculenta).

\section{The similarity of bird communities}

Based on similarity community Sorensen index (Tabel 5), the highest similarity of bird communities was discovered in associate between habitat of 2006 reclaimed land and natural forest $(\mathrm{Cn}=0.79)$. Meanwhile, an associate between habitat of 2016 reclaimed land and natural forest showed the lowest value with $\mathrm{Cn}=0.45$. Boer (2009) reported that the presence of birds on reclaimed land is a process toward the make up of the similar to natural forest. The value of similarity index was close to one, so birds found in reclaimed land was similar to natural forest. Generally, the number of bird species in natural forest was lower than in reclaimed land, but bird species found in the both natural forest and 2006 reclaimed forest tend to similar. This phenomenon was proved with the discovery of Sulawesi hornbill in both locations. Sulawesi hornbill usually prefer to inhabit in primary or secondary forest (Coates and Bishop 2000) that having big tree for living and nesting.

Table 3 Jackknife species richness index (S), Bird species diversity index (H'), Evenness index (E) of bird species on reclaimed land.

\begin{tabular}{ccccc}
\hline Research sites & Number of species & $\mathbf{S}$ & $\boldsymbol{H}^{\prime}$ & $\boldsymbol{E}$ \\
\hline Reclaimed land in 2006 & 34 & 44 & 3,08 & 0,87 \\
Reclaimed land in 2007 & 25 & 30,45 & 2,81 & 0,87 \\
Reclaimed land in 2009 & 19 & 22,64 & 2,43 & 0,83 \\
Reclaimed land in 2016 & 16 & 21,45 & 2,11 & 0,76 \\
Natural forest & 24 & 28,45 & 2,62 & 0,82 \\
\hline
\end{tabular}


Table 4 Dominance of bird species at the research site.

\begin{tabular}{|c|c|c|c|c|c|c|c|c|c|c|}
\hline \multirow{3}{*}{ Family / Latin Name } & \multicolumn{10}{|c|}{ Research sites } \\
\hline & \multicolumn{2}{|c|}{$\mathbf{A}$} & \multicolumn{2}{|c|}{ B } & \multicolumn{2}{|c|}{$\mathbf{C}$} & \multicolumn{2}{|c|}{ D } & \multicolumn{2}{|c|}{$\mathbf{E}$} \\
\hline & ID & Kat & ID & Kat & ID & Kat & ID & Kat & ID & Kat \\
\hline \multicolumn{11}{|l|}{ Nectariniidae } \\
\hline Cinnyris jugularis & 5 & $\mathrm{D}$ & 7 & $\mathrm{D}$ & 24 & $\mathrm{D}$ & 13 & $\mathrm{D}$ & 4 & SD \\
\hline Leptocoma sericea & 1 & $\mathrm{TD}$ & 4 & $\mathrm{SD}$ & 9 & $\mathrm{D}$ & 3 & $\mathrm{SD}$ & 14 & $\mathrm{D}$ \\
\hline Aethopyga siparaja & 1 & $\mathrm{TD}$ & 1 & $\mathrm{TD}$ & 1 & $\mathrm{TD}$ & 3 & $\mathrm{SD}$ & 7 & $\mathrm{D}$ \\
\hline \multicolumn{11}{|l|}{ Dicaeidae } \\
\hline Dicaeum aureolimbatum & 2 & $\mathrm{SD}$ & 5 & $\mathrm{D}$ & 3 & $\mathrm{SD}$ & 0,7 & $\mathrm{TD}$ & 8 & $\mathrm{D}$ \\
\hline Dicaeum celebicum & 6 & $\mathrm{D}$ & 7 & $\mathrm{D}$ & 9 & $\mathrm{D}$ & 4 & $\mathrm{SD}$ & 4 & $\mathrm{SD}$ \\
\hline \multicolumn{11}{|l|}{ Pycnonotidae } \\
\hline Pycnonotus aurigaster & 6 & $\mathrm{D}$ & 4 & $\mathrm{SD}$ & 4 & $\mathrm{SD}$ & 37 & $\mathrm{D}$ & 1 & $\mathrm{TD}$ \\
\hline \multicolumn{11}{|l|}{ Meropidae } \\
\hline Merops ornatus & 12 & $\mathrm{D}$ & 13 & $\mathrm{D}$ & 19 & $\mathrm{D}$ & 9 & $\mathrm{D}$ & 6 & $\mathrm{D}$ \\
\hline \multicolumn{11}{|l|}{ Psittacidae } \\
\hline Prioniturus flavicans & 0,6 & $\mathrm{TD}$ & - & - & - & - & - & - & 14 & $\mathrm{D}$ \\
\hline Loriculus stigmatus & 7 & $\mathrm{D}$ & 3 & $\mathrm{SD}$ & 6 & $\mathrm{D}$ & - & - & 0,3 & $\mathrm{TD}$ \\
\hline \multicolumn{11}{|l|}{ Dicruridae } \\
\hline Dicrurus hottentottus & 10 & $\mathrm{D}$ & 9 & $\mathrm{D}$ & - & - & - & - & 1 & $\mathrm{TD}$ \\
\hline \multicolumn{11}{|l|}{ Apodidae } \\
\hline Collocalia esculenta & 8 & $\mathrm{D}$ & 10 & $\mathrm{D}$ & 4 & $\mathrm{SD}$ & - & - & 9 & $\mathrm{D}$ \\
\hline \multicolumn{11}{|l|}{ Columbidae } \\
\hline Ptilinopus melanospila & 5 & $\mathrm{D}$ & 0,6 & $\mathrm{TD}$ & 3 & $\mathrm{SD}$ & 2 & $\mathrm{SD}$ & 1 & $\mathrm{TD}$ \\
\hline \multicolumn{11}{|l|}{ Alcedinidae } \\
\hline Halcyon chloris & 4 & $\mathrm{SD}$ & 5 & $\mathrm{D}$ & 4 & $\mathrm{SD}$ & - & - & 1 & $\mathrm{TD}$ \\
\hline \multicolumn{11}{|l|}{ Timaliidae } \\
\hline Trichastoma celebense & 4 & $\mathrm{SD}$ & 8 & $\mathrm{D}$ & 2 & $\mathrm{SD}$ & - & - & 15 & $\mathrm{D}$ \\
\hline \multicolumn{11}{|l|}{ Hemiprocnidae } \\
\hline Hemiprocne longipennis & 4 & $\mathrm{SD}$ & 8 & $\mathrm{D}$ & - & - & 0,7 & $\mathrm{TD}$ & 1 & $\mathrm{TD}$ \\
\hline \multicolumn{11}{|l|}{ Muscicapidae } \\
\hline Saxicola caprata & 0,6 & $\mathrm{TD}$ & 1 & $\mathrm{TD}$ & 0,4 & $\mathrm{TD}$ & 7 & $\mathrm{D}$ & - & - \\
\hline \multicolumn{11}{|l|}{ Zosteropidae } \\
\hline Zosterops chloris & 0,3 & $\mathrm{TD}$ & - & - & & & 11 & $\mathrm{D}$ & - & - \\
\hline Zosterops consobrinorum & 1 & $\mathrm{TD}$ & 4 & $\mathrm{SD}$ & 4 & $\mathrm{SD}$ & - & - & 6 & $\mathrm{D}$ \\
\hline
\end{tabular}

Description: A= Reclaimed land in 2006, B= Reclaimed land in Tahun 2007, C= Reclaimed land in Tahun 2009, $\mathrm{D}=$ Reclaimed land in Tahun 2016, E=Natural forest, ID=Dominance Index, Kat=Category, TD=Not dominant, $\mathrm{SD}=$ Sub Dominant, $\mathrm{D}=$ Dominant. 


\section{Vegetation condition in ex-mining land}

Vegetation analysis showed that there were 19 tree species found in reclaimed land (Tabel 6). In tree level, sengon and sengon buto dominated in all areal reclaimed land. Sengon had the highest IVI value of 134,67. The highest of IVI value in pile level was sengon buto (IVI = 108.71). Stake level was dominated by bitti (IVI = 40.69), while komba-komba dominated in breed level (IVI=46.12). Generally, reclaimed land in 2006, 2007, and 2009 had the similar pioneer plants. It was due to reclamation activities used fast growing species, such as sengon, sengon buto, bitti, kolaka, kayu kuku, dan tirotasi (Vale 2014).

During this study, vegetation was found to be flowering or fruiting phase (Table 6). There were more fruiting trees than flowering trees in reclaimed land. Meanwhile, the highest number of flowering trees was 30 individuals in 2016 reclaimed land. The high number of individuals was influenced by the abundance of natural succession plants, such as Trema sp (flowering and fruiting). 22 from 30 individual were Trema $s p$.

\section{The abundance of insect}

937 individuals from 87 family and 16 order were caught using the methods (Tabel 7). Myrmecocystus mexicanus from Formicidae family, order Hymenoptera was the most caught individuals (71 individuals). The presence of insect was influenced by environmental factors, such as air temperature, air humidity, soil humidity, light, rainfall, vegetation, and food sources. In ideal condition, the number of insects refers to the ages of reclamation. Meanwhile, this study reported that the number of insects was higher in 2009 reclaimed land. It was estimated cause of environmental factors, such as vegetation and air temperature. The average of air temperature in 2009 reclaimed land was about $24.69{ }^{\circ} \mathrm{C}$ which this temperature was close to optimal temperature $\left(25{ }^{0} \mathrm{C}\right)$ for insect breeding (Basna et al. 2017). In other hand, there was a small lake in 2009 reclaimed land. The surrounding condition affected to vegetation growth to be faster. The location of 2009 reclaimed land had more individual trees than the others. This condition increased the number of individual insects in 2009 reclaimed land.

\section{Environtmental factor affecting the presence of bird}

According to table 8, the variables $\mathrm{X} 2$ and $\mathrm{X} 3$ must be removed from multiple regression analysis because it has the value of VIF $>10$. The results of multiple regression analysis using five variables of environmental factors observed were the number of individuals insect, the number of tree species, and closest perpendicular distance to the river. The regression model formed is the relationship between the number of bird species (Y) with the number of individual insects (X5), the number of tree species (X6) and the closest perpendicular distance to the river $(\mathrm{X} 7)$, with the equation

The equation for predicting the presence of birds has a value of $\mathrm{R} 2=0.224$ with a significance value (Prob $>\mathrm{F})=0.000$ (Table 13). The variable number of individual insects has a significant correlation with the variable number of tree species, this is evidenced by the value of $r=0.309$ and Prob $>F=0.009$. The variable number of individual insects also has a high positive correlation with the temperature variable with a value ( $\mathrm{r}$ $=-0.275$, Prob $>\mathrm{F}=0.011$ ).

Table 4 Similarity community Sorensen Index $(\mathrm{Cn})$.

\begin{tabular}{cccccc} 
Research sites & $\begin{array}{c}\text { Reclaimed } \\
\text { land in 2006 }\end{array}$ & $\begin{array}{c}\text { Reclaimed } \\
\text { land in 2007 }\end{array}$ & $\begin{array}{c}\text { Reclaimed } \\
\text { land in 2009 }\end{array}$ & $\begin{array}{c}\text { Reclaimed } \\
\text { land in 2016 }\end{array}$ & $\begin{array}{c}\text { Natural } \\
\text { forest }\end{array}$ \\
\hline $\begin{array}{l}\text { Reclaimed land in 2006 } \\
\text { Reclaimed land in 2007 }\end{array}$ & 1 & 0,78 & 0,64 & 0,52 & 0,79 \\
Reclaimed land in 2009 & & 1 & 0,73 & 0,59 & 0,78 \\
$\begin{array}{c}\text { Reclaimed land in 2016 } \\
\text { Natural forest }\end{array}$ & & & 1 & 0,46 & 0,65 \\
\end{tabular}

Table 6 Flowering and fruiting trees on Research sites.

\begin{tabular}{lcccccc}
\hline \multirow{2}{*}{ Research sites } & \multicolumn{2}{c}{ Flowering trees } & & \multicolumn{2}{c}{ Fruiting trees } \\
\cline { 2 - 3 } \cline { 5 - 6 } & $\begin{array}{c}\text { Number of } \\
\text { species }\end{array}$ & $\begin{array}{c}\text { Number of } \\
\text { individuals }\end{array}$ & & $\begin{array}{c}\text { Number of } \\
\text { species }\end{array}$ & $\begin{array}{c}\text { Number of } \\
\text { individuals }\end{array}$ \\
\hline Reclaimed land in 2006 & 4 & 13 & & 8 & 132 \\
Reclaimed land in 2007 & 4 & 19 & & 6 & 121 \\
Reclaimed land in 2009 & 2 & 10 & & 5 & 48 \\
Reclaimed land in 2016 & 4 & 30 & & 3 & 13 \\
Natural forest & 6 & 19 & & 4 & 9 \\
\hline
\end{tabular}


Table 5 the abundance of the order and the number of individual insects.

\begin{tabular}{|c|c|c|c|c|c|c|}
\hline \multirow{2}{*}{ No } & \multirow{2}{*}{ Order } & \multicolumn{5}{|c|}{ Reclaimed land in } \\
\hline & & 2006 & 2007 & 2009 & 2016 & Hutan Alami \\
\hline 1 & Aranea & 58 & 55 & 75 & 38 & 46 \\
\hline 2 & Blattodea & 16 & 7 & 19 & 2 & 5 \\
\hline 3 & Coleoptera & 21 & 30 & 29 & 16 & 21 \\
\hline 4 & Diptera & 2 & 4 & - & - & - \\
\hline 5 & Dsycohoptera & - & 1 & - & - & - \\
\hline 6 & Hemiptera & 22 & 9 & 12 & 19 & 7 \\
\hline 7 & Hymenoptera & 32 & 51 & 41 & 15 & 16 \\
\hline 8 & Lepidoptera & 14 & 12 & 22 & 5 & 13 \\
\hline 9 & Mantodea & 3 & - & 4 & 1 & 2 \\
\hline 10 & Mecoptera & - & - & 1 & - & - \\
\hline 11 & Neuroptera & - & - & 3 & 1 & 1 \\
\hline 12 & Odonata & 12 & 21 & 7 & 22 & 24 \\
\hline 13 & Orthoptera & 24 & 12 & 27 & 11 & 14 \\
\hline 14 & Phasmatodea & - & 3 & - & 1 & 1 \\
\hline 15 & Pscoptera & - & - & 1 & - & 1 \\
\hline 16 & Psocodea & - & 1 & - & - & - \\
\hline 17 & Trichoptera & 4 & - & - & - & - \\
\hline & Total & 208 & 206 & 241 & 131 & 151 \\
\hline
\end{tabular}

Table 8 Tolerance value and VIF variable $\mathrm{X}$.

\begin{tabular}{lccccccc}
\hline \multirow{2}{*}{ Statistics } & \multicolumn{9}{c}{ Variables } \\
\cline { 2 - 8 } & $\mathbf{X}_{\mathbf{1}}$ & $\mathbf{X}_{\mathbf{2}}$ & $\mathbf{X}_{\mathbf{3}}$ & $\mathbf{X}_{\mathbf{4}}$ & $\mathbf{X}_{\mathbf{5}}$ & $\mathbf{X}_{\mathbf{6}}$ & $\mathbf{X}_{\mathbf{7}}$ \\
\hline Tolerance & 0,772 & 0,008 & 0,011 & 0,678 & 0,831 & 0,772 & 0,117 \\
VIF & 1,30 & 126,99 & 91,41 & 1,48 & 1,20 & 1,29 & 8,55 \\
\hline
\end{tabular}

Based on the equation of predictor factor of the bird presence, the number of tree species was the more influential variable compared to other variables, such as the number of individual insect and the closest perpendicular distance to the river. This condition was suitable with field data that the higher number of tree species was directly proportional to bird diversity index.

Negative mark of coefficient of distance perpendicular to the river showed that the increasing variable value explained to the reverse effect to number of bird species, so the higher of perpendicular distance to the river indicated the lower number of bird species. It is a similar report from Hawkins et al. (2015), there are a correlation of species diversity with the presence of water and the level of plant biomass.

\section{Conservation Implication}

The result showed that compared to the other reclaimed land, the 2006 reclaimed land had a similar composition to natural forest. Salek (2012) reported that the reclaimed land would be similar to natural forest with the increasing reclamation age. Vegetation succession increased species diversity with along time. The number of species trees found in reclaimed land were influenced by initial selection of vegetation types on reclamation activities. Using fast growing species (pioneer species) such as sengon and sengon buto on reclamation accelerated land covered by vegetation.

\section{CONCLUSION}

A total of 41 bird species from 23 families were found during the study. 17 of them were Sulawesi and Walacea endemic species. One of the was a migratory bird. 10 species were protected by Indonesia government rules. The highest species richness and diversity was found in year 2006 reclamation land (34 species, $S=44$, $\mathrm{H}^{\prime}=3,08$ ), while the lowest bird richness and diversity was found in 2016 reclaimed land ( 16 species, $\mathrm{S}=21,45$, $\left.\mathrm{H}^{\prime}=2,11\right)$. The similarity analysis of bird communities showed that reclaimed land in 2006 and natural forest had the highest value $(\mathrm{Cn}=0,79)$. The high number of 
bird species was influenced by the number of flowering and fruiting trees. The frugivorous birds found, namely green imperial pigeon (Ducula aenea), Sulawesi hornbill (Penelopides exarhatus), and yellow-breasred racket-tail (Prioniturus flavicans), in 2006 reclaimed land had the highest individual number of flowering and fruiting trees.

\section{REFERENCES}

Alamsyah, Sambernyowo G, Attong F, Misdar. 2011. Best practice reklamasi Lahan Bekas Tambang PT. Inco Tbk Project Pomalaa. Prosiding Seminar Nasional. Benarkah Tambang Mensejahterakan? Telaah Sulawesi Tenggara Sebagai Pusat Industri Pertambangan Nasional. BIOTROP SPECIAL PUPLICATION NO. 65 ISSN 0125-975X. Kendari.

Basna M, Koneri R, Papu A. 2017. Distribusi dan diversitas serangga tanah di Taman Hutan Raya Gunung Tumpa Sulawesi Utara. Jurnal Mipa Unsrat. $6(1): 36-42$

Bibby C, Jones M, Marsden S. 2000. Teknik-Teknik Ekspedisi Lapangan; Survey Burung. Bogor (ID): BirdLife International Indonesia Programme

Boer C. 2009. Keragaman avifauna pada lahan bekas tambang emas PT Kelian Equatorial Mining, Kutai Barat, Kalimantan Timur. JMTH. 15(2): 54-60.

Boland CRJ. 2004. Evolutionary Ecology of Rainbow Bee-eaters (Merops ornatus) [tesis]. Australia: The Australian National University.

Borror DJ, Triplehorn CA, Jhonson NF. 1996. Pengenalan Pelajaran Serangga. S Partosoetiono, penerjamah. Yogyakarta (ID): Gadjah Mada University Press. Terjemahan dari An Introduction to the Stufy Insect. Ed ke-6.

Brady JC. 2005. Birds as indicators of rehabilitation success at Gove Bauxite Mine [tesis]. Australia: Charles Darwin University.

Brady CJ, Noske RA. 2009. Succession in bird and plant communities over a 24-year chronosequence of mine rehabilitation in the Australian Monsoon Tropics. Restor Ecol. 18(6):855-864.

[BPS] Badan Pusat Statistik. 2020. Analisis Komoditas Ekspor 2012-2019, sektor pertanian, industri, dan pertambangan. Jakarta: BPS RI.

Coates BJ, Bishop KD. 2000. Panduan Lapangan Burung-Burung di Kawasan Wallacea (Sulawesi, Maluku dan Nusa Tenggara). Bogor(ID): BirdLife International Indonesia Programme

CSIRO. 1991. The Insects of Australia: a Teextbook for Students and Research Workers. Melbourne (AU): Melbourne Univ Press.

Darmono. 20011. Lingkungan Hidup dan Pencemaran: Hubungannya dengan Toksikologi Senyawa Logam. Jakarta. UI Press

Dewi RS, Mulyani YA, Santosa Y. 2007. Keanekaragaman jenis burung di beberapa tipe habitat Taman Nasional Gunung Ciremai. Medkon. 12(3). 114-118.

[ESDM] Ministry of Energy and Mineral Resources. 2020. Konferensi pers: perkembangan kebijakan sub sektor pertambangan mineral dan batubara [Internet]. [diunduh 2021 June 12]. Tersedia pada: https://www.minerba.esdm.go.id/berita/minerba/detil/ 20200312-konferensi-pers-perkembangan-kebijakansub-sektor-pertambangan-mineral-dan-batubara

Fachrul MF. 2008. Metode Sampling Bioekologi. Jakarta (ID): Bumi Aksara.

Furness RW. 1993. Birds as monitors of pollutants. In: Furness RW, Greenwood JJD. (eds) Birds as Monitors of Environmental Change. Dordrecht: Springer. Doi: https://doi.org/10.1007/978-94-015$1322-7 \quad 3$

Hawkins BA, Diniz-Filho JAF, Soeller SA. 2005. Water links the historical and contemporary components of the Australian bird diversity gradient. $J$ Biogeogr. 32:1035-1042.

Helvoort B. 1981. A Study of Bird Population in The Rural Ecosystem of West Java, Indonesia: a Semi Quantitative Approach. Wageningen(NL) : Nate Conservation Dept Agriculture University Wageningan.

Herrando S, Bronton L. 2002. Forest bird diversity in Mediterranean areas affected by wildfires: a multiscale approach. Ecography. 25(2):161-172.

Hidayat W. 2015. Dampak Pertambangan Terhadap Perubahan Penggunaan Lahan dan Kesesuaian Peruntukan Ruang (Studi Kasus Kabupaten Luwu Timur, Provinsi Sulawesi Selatan). Jurnal Perencanaan Wilayah dan Kota. 26(2) 2015:130-146.

[INSG] Internasional Nickel Study Group. 2018. The World Nickel Factbook 2018. Lisbon(PT): INSG.org.

[IUCN] International Union for Conservation of Nature. 2020. The IUCN Red List of Threatened Species [internet]. [diunduh 2020 Juli 15]. Tersedia pada: https://www.iucnredlist.org/

Julliard R, Clavel J, Devictor V, Jiguet F, Couvet D. 2006. Spatial segregation of specialists and generalists in bird communities. Ecol Lett. 9: 12371244. Doi: 10.1111/j.1461-0248.2006.00977.x

Kaban A. 2018. Komunitas burung pada struktur lanskap berbeda di Kota Bogor, Jawa Barat [tesis]. Bogor: Institut Pertanian Bogor.

Karr JR. 1968. Habitat and avian diversity on strip-mined land in east-central Illinois. The Condor. 70:348-357.

[Kemenperin] Kementerian Perindustrian Republik Indonesia. 2017. Sumbang 18 persen, industri nonmigas jadi kontributor terbesar ekonomi [Internet]. [2021 Mart 21]. Tersedia pada https://www.kemenperin.go.id/artikel/17985/Sumban g-18-Persen,-Industri-Non-migas-Jadi-KontributorTerbesar-Ekonomi

[KLHK] Kementrian Lingkungan Hidup dan Kehutanan. 2018. PERMEN LHK RI Nomor: P.106/Menlhk/ 
Setjen/Kum 1/6/2018: Tentang Jenis Tumbuhan dan Satwa Dilindungi. Indonesia: Peraturan Menteri Lingkungan Hidup dan Kehutanan Republik Indonesia.

Ludwig JA, Reynolds JF. 1988. Statistical Ecology a Primer on Methods and Computing. United State of America (AS): A Wiley-Interscience Publication

MacKinnon J.1990. Panduan Lapangan Burung-Burung di Jawa dan Bali. Yogyakarta: Gajah Mada University Press.

Maga, Ismail A, Falatehan AF. 2017. Merumuskan kebijakan dalam mengatasi kerusakan lingkungan akibat aktivitas tambang nikel di kecamatan tinanggea kabupaten konawe selatan. Risalah Kebijakan Pertanian dan Lingkungan. 4(2): 125-142.

Magurran AE, McGill BJ. 2011. Biological Diversity Frontiers in Measurement and Assessment. New York: Oxford University Press Inc

Magurran AE. 2004. Measuring Biological Diversity. Oxford(UK): Blackwell Publishing Company.

Meijer K, Smit C, Beukeboom LW, Schilthuizen M. 2012. Native insect on native plants in The Netherlands: curiosities or common practice? Entomol Ber. 72(6): 288-293.

Morrison ML. 1986. Bird Populations as Indicators of Environmental Change. Boston (UK): Springer. Doi: https://doi.org/10.1007/978-1-4615-6784-4_10

Mustari AH, Asmoro AWT, Pi GOE. 2012. Keanekaragaman jenis burung di Taman Nasional Bantimurung, Bulusaraung, Sulawesi Selatan. Medkon. 17(3): 138-142

N'Djolossè K, Atachi P, Gnanglè CP. 2012. Inventory of Insect associated with shea trees (Vitellaria paradoxa) (Sapotaceae) in Central and Northern Benin. Int $J$ Trop Insect Sc. 32(3):158-165.

Prawiradilaga DM. 2019. Keanekaragaman dam Strategi Konservasi Burung Endemik Indonesia. Jakarta: LIPI Press.

Rahayuningsih M, Mardiastuti A, Prasetyo LB, Mulyani YA. 2007. Bird community in Burung Island, Karimunjawa National Park, Central Java. Biodiversitas. 8(3): 183-187.

Salek M. 2012. Spontaneous succession on opencast mining implications for bird biodiversity. J Appl Ecol. 149 : 1417-1245.
Sastranegara H. 2018. Pemilahan guild burung insektivora diurnal di empat tipe habitat Taman Nasional Baluran [tesis]. Bogor:Institut Pertanian Bogor.

Sergio F, Newton I, Pedrini P. 2006. Ecologically justified charisma: preservation of top predators delivers biodiversity conservation. J Appl Ecol. 43 (6): 1049-1055.

Soegiharto S, Zuhud EAM, Setiadi Y, Masyud B. 2017. Indikator kunci pemulihan fungsi habitat burung di lahan reklamasi dan revegetasi pasca tambang batubara. J Biologi Indones. 13(2): 297-304

Soerianegara I, Indrawan A. 1980. Ekologi hutan Indonesia. Bogor: Institut Pertanian Bogor.

Stone C, Bacon PE. 1994. Insect herbivory in a River Red Gum (Eucalyptus camaldulensis Dehnh.) Forest in Southern New South Wales. J Aust ent Soc. 33: 5156.

Sukmantoro W, Irham M, Novarino W, Hasudungan F, Kemp N, Muchtar M. 2007. Daftar Burung Indonesia No 2. Bogor (ID): IdOU (Indonesian Ornithologist's Union.

[USGS] United State Geological Survey. 2020. Mineral commodity summaries 2020.: Reston: US Geological Survey (US). Doi: https://doi.org/10.3133/mcs2020.

Vale. 2014. Rencana Kerja Tahunan Teknis Dan Lingkungan (RKT-TL) PT Vale Indonesia Tbk (VALE) Periode Tahun 2014. Kolaka (ID): PT Vale Tbk Indonesia

Vikar A, Kartono AP, Mulyani YA. 2020. Komunitas burung pada ruang terbuka hijau di Kota Palu Provinsi Sulawesi Tenggara. Medkon. 25(1): 26-35.

Walpole RE. 1992. Pengantar Statistika.Jakarta (ID): Gramedia.

Wiens JA. 1992. The Ecology of Bird Communities. Cambridge (UK): Cambridge University Press.

Yassir I, Atomoko T, Afifudin S. 2013. Jenis-jenis burung di lahan terdegradasi sebagai pemencar biji dan pengendali populasi serangga: studi kasus di lahan alang-alang dan bekas tambang batubara. Prosiding. 27 November 2013. "Reklamasi Lahan Pasca Tambang: Aspek Kebijakan, Konservasi dan Teknologi". 